\title{
DERECHO Y MORAL (RAZÓN PRÁCTICA): CONEXIONES EN TIEMPOS DEL ESTADO DE DERECHO CONSTITUCIONAL ${ }^{*}$
}

\author{
LAW AND MORALITY (PRACTICAL REASON): CONNECTIONS \\ IN TIMES OF THE CONSTITUTIONAL RULE OF LAW
}

Rodolfo Luis VIGO*

\section{Resumen:}

El Estado de derecho constitucional hizo visibles conexiones entre el derecho y la moral racional, y en ese punto, el "movimiento de rehabilitación de la razón práctica" de la década de los setenta, inspirado fuertemente en autores como Kant y Aristóteles, aportó un marco teórico funcional a esos fines. Son ejemplos ilustrativos de dicha afirmación las teorías jurídicas de Robert Alexy (dialógica-constructivista) y John Finnis (realista-iusnaturalista), que avalan - con distintos fundamentos - hasta nueve conexiones entre el derecho y la moral, las que facilitan una comprensión y operatividad del derecho al servicio de un objetivamente mejor o más valioso derecho. Si no hay razón capaz de definir lo bueno o lo malo, lo justo o lo injusto se frustra ese propósito y se mantiene la distancia entre aquellas dos disciplinas y realidades inescindiblemente humanas.

\section{Palabras clave:}

Estado de derecho constitucional, razón práctica-derecho, moral racional, cognitivismo moral, escepticismo moral.

\section{Abstract:}

Constitutional Rule of Law has exposed connections between law and rational morality, and on this point, the 1970s "movement for the rehabilitation of

Artículo recibido el 7 de octubre de 2020 y aceptado para su publicación el 9 de diciembre de 2020.

** Profesor e investigador de la Pontificia Universidad Católica Argentina, correo: vigorodolfo@gmail.com, ORCID: https://orcid.org/0000-0002-8305-0374.

Problema. Anuario de Filosofía y Teoría del Derecho, núm. 15, enero-diciembre de 2021, pp. 53-96 Ciudad de México, ISSN 2007-4387, se distribuye bajo una Licencia Creative Commons ReconocimientoNo-Comercial-Sin Derivados 4.0 Internacional (CC BY-NC-ND 4.0). 


\section{RODOLFO LUIS VIGO}

practical reason" heavily inspired by writers like Kant and Aristotle, provided a functional theoretical framework to these ends. Some examples illustrating this statement are Robert Alexy's (dialogic-constructivist) and John Finnis's (realist-iusnaturalist) legal theories, which endorse -on different grounds- up to nine connections between law and morality, facilitating an understanding and operability of law to serve an objectively better or more valuable law. If there is no reason capable of defining what is good or bad, just or unjust, this objective is thwarted and the distance between these two inseparably human domains and realities is preserved.

\section{Keywords:}

Rule of Law, Constitutional State of Law, Practical Reason, Rational Morality, Moral Cognitivism, Moral Scepticism. 
DERECHO Y MORAL (RAZÓN PRÁCTICA)...

Sumario: I. Propósito y presupuestos. II. La moral como límite de la existencia o validez del derecho. III. La moral como elemento favorecedor en la creación del mejor derecho. IV. La moral como elemento favorecedor de la mejor aplicación del derecho. V. La moral para el mejor conocimiento jurídico. VI. La moral personal como límite al cumplimiento de la norma jurídica. VII. La moral como facilitadora de la eficacia de la norma jurídica. VIII. La moral como complemento de la coerción jurídica. IX. La moral como antídoto al insularismo jurídico. X. La moral del operador jurídico para el mejor derecho. XI. Conclusión. XII. Referencias.

\section{PROPÓSITO Y PRESUPUESTOS}

En el presente artículo nos proponemos identificar algunas conexiones entre el derecho y la moral racional las que, en algún sentido, son intrínsecas al derecho mismo, pero que a la luz de diversas teorías y autores no positivistas hoy en el marco del Estado de derecho constitucional (EDC) parecen más visibles o más fáciles de consentirlas. Bajo el predominio del Estado de derecho legal (EDL) y las teorías positivistas que le eran funcionales (iuspositivismo legalista o decimonónico y el iuspositivismo normativista o kelseniano), resultaba difícil aceptarlas a tenor del aparato conceptual y el modelo epistemológico que proponían. A lo largo de la segunda mitad del siglo XX se ha ido forjando en Europa continental el Estado de derecho constitucional que ha requerido e impuesto una nueva agenda al derecho, pero además se ha producido, sobre todo a partir de la década de los setenta, una significativa "rehabilitación de la razón práctica"1 inspirándose de manera original especialmente en Aristóteles y en Kant.

En estos tiempos se corrobora la presencia muy influyente de autores no positivistas que coinciden en la posibilidad de recurrir a la razón a los fines que brinden respuestas a preguntas de índole mo-

1 Cfr. Reidel, Manfred, Rehabilitierung der praktischen Philosophie, Freiburg i. Br., 2 vol.,1972-1974 y Volpi, Franco, "La rinascita della filosofia pratica in Germania”, en Pacchiani, C. (ed.), Filosofia pratica e scienza política, Abano-Padova,1980. 
ral, ética o valorativa. Dicho cognitivismo y objetivismo axiológico se traduce en varias coincidentes tesis operativas en el derecho, aunque también se mantienen diferencias que se explican por la matriz realista o constructiva a la que apelan. En un relevamiento rápido de los autores en los que estamos pensando, podemos mencionar por el lado de los que se apoyan en Aristóteles y Tomás de Aquino en John Finnis, Francesco Viola, George Kalinowski, Andrés Ollero, etcétera, y por el lado de los que remiten a propuestas constructivistas kantianas señalemos a Robert Alexy, Carlos Nino, Manuel Atienza, Neil MacCormick, etc. Subrayemos que lo decisivo es haber recuperado para los juristas una dimensión de la razón que está en condiciones de discernir y justificar argumentativamente que una cierta conducta o la norma que la regula, es mejor o más valiosa que otra, dado que aporta mejor o más claramente a los valores o bienes humanos que debe promover el derecho. En este punto digamos con Alexy $^{2}$ que después de dos mil años sigue habiendo dos posiciones centrales sobre el concepto del derecho: la positivista y la no positivista, y la clave distintiva es que mientras la primera rechaza la conexión necesaria entre derecho y moral la segunda la afirma.

Asimilaremos a la moral con la ética por razones básicamente etimológicas y más allá de los desencuentros entre esos dos términos que se dan después de Hegel, sobre todo. Ética viene del griego ethos, que dejando al margen las discusiones sobre su significado, podríamos acordar finalmente que equivale a "modo de ser" o "carácter" que el hombre va adquiriendo o incorporando a lo largo de su existencia. ${ }^{3}$ Del latin mos o mores deriva moral, y según textos de Cicerón aquellos términos pueden traducirse como "costumbre" y también carácter. En Aquino tenemos pistas más precisas: "la moral es la ciencia que enseña a los hombres a guiarse con la razón",4 y por eso "las virtudes... son conforme con la naturaleza humana en la medida que están de acuerdo con la razón; los vicios son contrarios

2 Alexy, Robert, El concepto y la validez del derecho, Barcelona, Gedisa, 1997, p. 13.

Aranguren, José Luis, “Etica”, Revista de Occidente, Madrid, 1958, p. 25.

4 Aquino, Tomás de, "Scientia moralis docet hominis sit bona ex hoc quod et secundum rationem rectam...", Comm. Eth. L.2,lec.2. 
a la naturaleza humana en la medida que son contrarios al orden de lo razonable". ${ }^{5}$ Desde esa matriz Finnis insiste: "El criterio de conformidad o contrariedad respecto a la naturaleza humana es la razonabilidad... El bien del ser humano es estar conforme con la razón y el mal humano es estar fuera del orden de la razonabilidad". ${ }^{6} \mathrm{Y}$ en cuanto al saber práctico precisa:

lo que es práctico es acerca de qué cosa hacer... No es acerca de lo que es el caso ,tampoco acerca de lo que será el caso... Una ciencia o teoría es práctica en el sentido más pleno si ella es acerca de y dirigida hacia aquello que es bueno hacer, tener, obtener y ser... Es práctica en su sentido más pleno cuando es acerca , y prescribe, lo que ha de ser hecho en el campo abierto a fines de la vida humana en su conjunto por elecciones y actos... en vista de objetos, fines-bienes que proveen razones para obrar y otorgan sentido a la vida individual o grupal como un todo abierto a fines, ${ }^{7}$

\section{y esas razones para obrar son los bienes humanos básicos:}

En el caso de los seres humanos, los objetos que han de ser entendidos antes que se pueda entender y conocer la naturaleza humana son los bienes humanos que son los objetos de nuestra voluntad, i.e. que son nuestras razones básicas para la acción y para dar razón a todo aquello que se puede, de modo inteligente, tener interés en elegir. ${ }^{8}$

En definitiva, actuamos procurando bienes que nuestra voluntad pretende y que la razón debe discernir, porque su posesión provee la felicidad respectiva. A tenor de esa conjunción, Millán Puelles señala que una ética realista cuenta con tres condiciones: "el amor de sí mismo, la búsqueda de felicidad y el placer". 9

5 Aquino, Tomás de, "Scriptum Super Libros Sententiarum Petri Lombardiensis" IV,d.2,q.1,a.4,so.l.1,ad.2

6 Finnis, John, Ley natural y derechos naturales, Buenos Aires, Abeledo Perrot, 2000, p.69

7 Finnis, John, Aquinas. Moral and Legal Theory, Oxford, Oxford University Press,1998, pp. 38-41.

8 Finnis, John, Collected Essays, vol. I, “Reason in Action”, Oxford, Oxford University Press, 2011, pp. 204 y 205.

9 Millan Pueles, Antonio, Ética y realismo, Madrid, Rialp, 1996, p. 32. 
Vayamos a Kant. Para el filósofo de Königsberg el conocimiento especulativo versa sobre el mundo empírico y su fuente es la razón pura; el conocimiento práctico refiere al mundo inteligible y su fuente es la razón pura en su uso práctico, es decir, la voluntad. La moral kantiana se aparta de las exigencias planteadas por la razón especulativa, y a diferencia de la moral clásica que se funda en el bien y en la metafísica, en el criticismo el proceso es el inverso, es decir, el deber determina el bien, y la moral funda la metafísica. Kant descarta la "materia" de la ley y sólo se queda con la "forma" de la ley, no interesa lo que se ha de obrar sino del modo con que se ha de obrar. La forma a priori de la razón práctica es aquel imperativo que garantiza la universalidad y necesidad de la moral. Kant enuncia el imperativo categórico utilizando distintas fórmulas, las tres más recordadas dicen: "obra de tal modo que la máxima de tu voluntad pueda siempre valer como principio de una legislación universal"; "obra de tal modo que nunca tomes la humanidad ni en ti en otros como medio, sino siempre como fin", y "obra de tal modo que tu voluntad pueda ser considerada como legisladora universal". ${ }^{10}$

Kant niega la posibilidad de fundar la moralidad de un acto sobre su objeto, o sea sobre su "materia", pues la bondad de un acto depende exclusivamente de su "forma", es decir, por la intención que lo anima, y tendrá valor moral si se ajusta al deber dictado por la razón, por el deber mismo, dado que si es realizado por inclinación carece de aquel valor. La "buena voluntad" — declara Kant- es lo único bueno en sí, pero ella "no es buena por lo que efectúa o realice... es buena sólo por el querer; es decir, es buena en sí misma".11 "El destino verdadero de la razón es producir una buena voluntad",12 y ésta se logra cuando se procede sin consideración de ventajas e intereses y ajustándose al deber por el deber mismo. El valor moral aparece cuando se obra bajo el solo móvil del "respeto a la ley", pues "el concepto del deber contiene el de buena voluntad". Alexy se inscribe en esa moral discursiva inspirada en Kant, que procura prolon-

10 Citado por González Álvarez, Ángel, Manual de Historia de la Filosofía, Madrid, Gredos, 1960, p. 384.

11 Fraile, Historia de la Filosofía, t. V, p. 84.

12 Idem. 
gar el proyecto ilustrado de la modernidad y confirmar los rasgos de universal, cognitivista y formal. El campo escogido por el profesor de Kiel para esa peculiar racionalidad práctica, será el uso del lenguaje y la racionalidad consensual-comunicativa presupuesta en el mismo, la que en definitiva transita por el discurso argumentativo. Así, la razón ya no sólo estará habilitada para la verdad en el campo teórico, sino que también se legitima en su búsqueda de la "corrección" de normas y juicios de valor. Alexy concluye inequívocamente: "Los problemas de la justicia son problemas morales"13 y es posible argumentar racionalmente en materia de justicia; lo que posibilita superar la posición emotivo-subjetiva". Pero la Diskurstheorie no solo se aparta de "las teorías emotivistas, subjetivistas, relativistas y decisionistas" en tanto desconocen que "los juicios de justicia son verdaderos y propios juicios mediante los cuales avanza una pretensión de corrección", sino también del "objetivismo radical" en tanto "asimila en medida excesiva los juicios de justicia a normales juicios de hecho". ${ }^{14}$

Sintéticamente, y sin perjuicio de las ampliaciones que siguen, subrayemos que tanto aquella teoría jurídica aristotélica-tomista de Finnis como la de Alexy de base kantiana, no duda en reclamar conexiones esenciales entre el derecho y la razón práctica, y precisamente, es esta última la que le brinda la posibilidad de juzgar y reclamar un derecho objetivamente más justo o más bueno para el hombre y la sociedad. La moral, por ambas propuestas, aunque con fundamentos y alcances distintos, deja de ser una cuestión de gustos y elecciones irracionales, y esa definición tienen muchas proyecciones. Quizás pueda ser oportuno para cerrar esta presentación en donde intentamos defender la tesis que avalada la razón en el campo de la moral, ella de manera muy obvia ${ }^{15}$ se proyecta al campo jurídico en aras del mejor derecho, recurrir a un autor influyente y

13 Alexy, Robert, "Derecho y Moral", p. 87.

14 Alexy, Robert, “La justicia como corrección”, Doxa, núm. 26, 2003, p. 164.

15 No ignoramos que hay autores que a pesar de su objetivismo ético mantienen una férrea visión iuspositivista (por ejemplo Jeremy Betham) que admite cualquier contenido como derecho, pero ello nos parece contraintuitivo, contradictorio o hasta esquizofrénico, o sea, afirmar que puedo saber lo que es justo o lo que es conveniente para la vida social, pero tolero o acepto cualquier contenido como derecho 
que a lo largo del tiempo fue modificando su teoría jurídica de modo más armónico con lo que defendemos en este artículo, nos referimos a Neil MacCormick cuando concluye:

La tesis de que hay algo así como razón práctica y que el derecho pertenece al ejercicio (por más defectuoso que sea) de la razonabilidad práctica tiene, por consiguiente, una importancia fundamental. Es la base de la pretensión que hay una conexión necesaria entre derecho y moralidad: ambos están vinculados por ser modos de ejercicio de la razón práctica, y al mismo tiempo difieren por ser modos diferentes de ella, teniendo diferentes criterios de validez para las normas o reglas que aplican. ${ }^{16}$

Somos conscientes que en las nueve conexiones que trataremos a continuación hay cierta superposición o solapamiento en los temas que nos hemos forzado en distinguir, pero esa debilidad puede compensarse en orden a matices o insistencias que refuerzan lo central que buscamos en estas líneas.

\section{LA MORAL COMO LÍMITE DE LA EXISTENCIA O VALIDEZ DEL DERECHO}

En el iuspositivismo legalista la ley se suponía que era justa dado que la había generado la voluntad general infalible del legislador (Rousseau), por ende, quedaba inhabilitada la posibilidad de controlarla o cuestionarla axiológicamente. La moral es algo totalmente ajeno al derecho a tenor de los tres conocidos criterios heredados de Kant (autonomía-heteronomía; incoercibilidad-coercibilidad; unilateralidad-bilateralidad), y la libertad tiene como único límite el de la ley. Kelsen enrolado en el escepticismo ético estricto afirma que "la justicia es un ideal irracional”, y así los juicios axiológicos valen todos iguales y deben confinarse a las emociones o voluntades individuales

16 MacCormick, Neil, "The Separation of Law and Morals", en George, Robert P., Natural Law Theory-Contemporary Essays, Oxford, Clarendon Press, p. 120, cabe destacar que en trabajos posteriores el profesor escocés profundizó sus convicciones postpositivistas y de una razón práctica objetivista en moral. 
o sociales. En esa matriz, y a los fines de la plenitud hermética del sistema jurídico, se reitera que lo que no está prohibido está permitido.

Una de las tesis iniciales centrales de Alexy"17 es que "El diálogo racional necesita del derecho para alcanzar realidad, y el derecho necesita del diálogo racional para alcanzar legitimidad". Ella resume que el derecho cubre debilidades del diálogo racional (tiempo, cumplimiento de lo acordado y problemas muy complejos) y que remiten a la pretensión de corrección que acompaña todo acto de aseveración. El diálogo con sus reglas definidas por la razón práctica procedimental, es el camino que tenemos para resolver nuestras aseveraciones contradictorias, y el seguimiento de las mismas posibilita obtener respuestas racionales a problemas referidos a juicios sobre el bien o lo que es justo. Al derecho le cabe optar entre lo "discursivamente posible" que se genera en el diálogo, y la aceptación de éste supone suscribir los derechos humanos, dado que ellos son presupuestos éticos de esa matriz racional. Alexy con empeño ha defendido la fórmula de Radbruch, según la cual "la injusticia extrema no es derecho", asumida por el Tribunal de Nuremberg y también empleada en la sentencia que condena a los soldados que cuidaban el muro de Berlín. Ese límite ético opera incluso para la Constitución, de manera que si ella incurre en una violación grave y evidente de los derechos humanos, eso no puede ser considerado como derecho. La existencia o validez del derecho requiere la dimensión institucional (órganos, normas y sistema) y cierta eficacia social, pero hay que sumarle un tercer requisito ya no positivista: el juzgamiento de su contenido ético objetivo en orden a confirmar que no supera el umbral de la injusticia extrema.

Es Finnis ${ }^{18}$ el representante más difundido de la "nueva escuela anglosajona de derecho natural", cuya peculiaridad distintiva es apartarse del camino más frecuente usado por la escuela aristotélica-tomista de derivar de la metafísica o la antropología el contenido ético que debe consagrar o proteger el derecho positivo, y preferir otro camino, cual es que esa juridicidad indisponible se obtenga desde el plano gnoseológico. Los derechos humanos son una

17 Remito a mi libro Perspectivas iusfilosóficas contemporáneas, Buenos Aires, Abeledo Perrot, 2019, pp. 228-280.

18 Ibidem, pp. 281-315. 
forma de expresar las exigencias de la razón práctica, la justicia y el bien común, pero esos conceptos valorativos, morales o axiológicos remiten a los "bienes humanos básicos" que cualquier ser humano, a partir de experiencias elementales y universales, aprehende y procura obtener, como, por ejemplo: la vida, la amistad, el juego, el conocimiento, etcétera. Esos bienes básicos son pre-morales, dado que aún antes del dominio de la razón y la libertad los seres humanos los apreciamos, aunque ellos se convierten en plenamente morales cuando ya corresponde asumir la propia conducción de nuestras vidas. Los derechos humanos son la protección jurídica que se les brinda a esos bienes básicos, y éstos coinciden con los principios más generales (commnisima) de la ley natural de los cuales derivamos las formas básicas que podemos asumir en aras de nuestro "florecimiento". Una de las claves de la teoría finnisiana es el recurso a la analogía, que permite distinguir en el uso de ciertos conceptos aquellos ejemplares maduros, completos o acabados de los que son desviados, corrompidos o incompletos. Precisamente al analizar la tesis tomista sobre que la ley injusta es "corruptio legis", Finnis ${ }^{19}$ no sólo destaca que se trata de una metáfora y que remite a situaciones realmente excepcionales, sino que fundamentalmente intenta, más que negarle naturaleza jurídica a ese ejemplar de la ley injusta, atribuirle un carácter debilitado, incompleto o deficitario.

Si un jurista renuncia a incluir en su mirada a la perspectiva de una moral racional corre el riesgo de tener que aceptar o validar que existen normas en el derecho no obstante que a tenor ético de su contenido o su gestación no corresponden que así se las reconozca. Nino habló de un "teorema fundamental de la teoría general del derecho" en la coincidencia entre normas jurídicas y normas morales: "Hay casos de normas morales que son normas jurídicas puesto que la clase de normas jurídicas justificatorias es una especie de las clases morales; no todo principio o juicio moral es una norma jurídica, pero toda norma jurídica que tiene un rol de razón operativa en el razonamiento práctico es un juicio moral". ${ }^{20}$ Hay un contenido moral

19 Remito a mi artículo "Consideraciones sobre la visión de John Finnis acerca de la tesis "la ley injusta no es ley", disponible en: http//biblio.juridicas.unam.mx.

20 Nino, Carlos, “Sobre los derechos morales", Doxa, núm. 7, p. 322. 
objetivo y mínimo pero infranqueable que la razón le pone a la autoridad con competencia jurígena, y ese es el valor con los que se consagra el "coto vedado" o la "juridicidad indisponible" de los derechos humanos según los tratados respectivos, los que simplemente se limitan a reconocerlo (no los crean), en el espacio universal y con el carácter de inalienables (por cualquier voluntad pública o privada). El valor de los derechos humanos no deriva de su reconocimiento jurídico, sino que más bien, atento al valor humano intrínseco de los mismos, el derecho no tiene otra alternativa que protegerlos si pretende ponerse al servicio del hombre y la sociedad. El medio de acceso a dicho contenido moral (moral rigths) es la razón humana armónica con las demás facultades humanas. De ese modo, si la moral la pone cada uno (Kelsen), cada sociedad (Duguit), la voluntad divina (Lutero), las normas jurídicas positivas (Rousseau) o depende sólo de las consecuencias (Bentham), no será posible enarbolar la bandera de la injusticia extrema o los derechos humanos inalienables.

Massini $^{21}$ ha destacado cierta coincidencia de Finnis con Alexy acerca de la tesis por este último defendida sobre la naturaleza dual del derecho: la dimensión fáctico-institucional y la dimensión racional-valorativa, lo que generó un intercambio de artículos entre ellos. También un conocedor profundo del pensamiento de Alexy, como lo es Carlos Bernal Pulido ha encontrado conexiones importantes con la teoría jurídica de Finnis. ${ }^{22}$

\section{LA MORAL COMO ELEMENTO FAVORECEDOR EN LA CREACIÓN ${ }^{23}$ DEL MEJOR DERECHO}

La pregunta central acerca de cómo se crea el derecho se focaliza en relación a la razón y a la voluntad humana. La tesis aristotélica que "la ley es razón sin pasión", será impugnada por el voluntarismo explícito y extremo de Hobbes proclamando: "auctoritas, non veritas,

21 Massini-Correas, Carlos I., Jurisprudencia analítica y derecho natural, Madrid, Marcial Pons, 2019, p. 176.

22 Bernal Pulido, Carlos, La doble dimensión del derecho, Lima, Palestra, 2011, p. 25.

${ }^{23}$ Si bien tenemos muchas reservas para distinguir entre creación y aplicación, la mantenemos en este trabajo en razón de su aceptación más generalizada. 
facit legem". En el siglo XIX, al hilo de la Revolución francesa y Rousseau, se hará realidad que es el querer y la decisión del legislador lo que constituye al derecho raigalmente. Basta comunicar al ciudadano lo que se ha decidido, resultando irrelevantes o prescindibles el porqué o el para qué. Kelsen excluye de la teoría jurídica los valores y el fin de la norma, pues ellos no se necesitan para una descripción científica objetiva de la misma, y el rechazo de la razón práctica implica la imposibilidad de brindar justificaciones racionales acerca de las bondades de lo prescrito.

En el marco de la "rehabilitación de la razón práctica", se inscribe la propuesta alexyana de que el discurso jurídico es un "caso especial” del discurso práctico general que la razón ha diseñado con veintiocho reglas formales o procedimentales bajo la promesa de alcanzar respuestas morales o valorativas objetivamente correctas. El profesor de Kiel explica esa "especialidad": "La conexión que la teoría del discurso crea entre los conceptos de corrección, de justificación y de generalizabilidad, puede transportarse al derecho con la ayuda de la tesis de que el discurso jurídico es un caso especial del discurso práctico general", ${ }^{24}$ y esos condicionamientos de los discursos jurídicos consisten en: "La sujeción a la ley, la obligada consideración de los precedentes, su encuadre en la dogmática elaborada por la ciencia jurídica organizada institucionalmente, así como... las limitaciones a través de las reglas del ordenamiento procesal".25 De esa integración resultará que el discurso jurídico asume una dimensión autoritativa, real o institucional junto a otra dimensión discursiva o ideal. Recordemos que la opción por el discurso racional implica la opción por los derechos humanos, lo discursivamente posible y, finalmente, la fórmula de Radbruch. Alexy excluye de la decisión legislativa el ámbito de la "moral personal" (cómo quiero vivir o qué es lo bueno para mí), aunque reconoce como límite de la misma a la moral pública, es decir, "aquello que ciudadanos racionales con concepciones personales del bien distintas consideran como condi-

24 Alexy Robert, Derecho y razón práctica, México, Fontamara, 1993, p. 55.

25 Alexy Robert, Teoría de la argumentación jurídica, Madrid, Centro de Estudios Constitucionales, 1989, p. 36. 
ciones de cooperación social justa tan importantes como para que el simple legislador no pueda decidir sobre ello". ${ }^{26}$

La definición del derecho finnisiana incorpora no sólo que "el derecho es un orden coactivo", sino "que regula su propia creación", pero además asume explícitamente las ocho desideratas o exigencias que integran la "moral interna" o el "derecho natural procesal" formuladas por Lon Fuller. Aunque para alcanzar su "definición focal" advierte que

la preocupación principal de una teoría de la ley natural es identificar de esa manera los principios y los límites del imperio del derecho, y encontrar las normas en que las leyes razonables, con toda su positividad y mutabilidad, han de ser derivados (no deducidos, normalmente) de principios inmutables - principios que reciben su fuerza de la razonabilidad, no de cualquier acto o acontecimiento originario. ${ }^{27}$

Destaquemos en la definición finnisiana algunos rasgos característicos: i) la matriz del derecho es la razonabilidad práctica, tanto la sustancial de los bienes humanos básicos que son absolutos en tanto no pueden ser sacrificados en ninguna opción, como la procedimental reflejada en las exigencias de Fuller que obstaculizan "la eficiencia para el mal de un gobierno malo"; ${ }^{28}$ ii) en ese plano formal o procedimental agreguemos que Finnis menciona nueve exigencias que expresan el método de la «ley natural» para elaborar la «ley natural» a partir de los primeros principios de la ley natural (premorales)", ${ }^{29}$ iii) frente a los dos modos de derivación del derecho positivo enseñados por Tomás, Finnis debilita la "conclusión" (derecho positivo per accidens") frente a la "determinación autoritativa (derecho positivo simpliciter); iv) con elocuencia concluye Finnis que el derecho es "el sendero común para perseguir el bien común", y aquí el valor moral de la autoridad que está encomendada de organizar racionalmente la coordinación en la sociedad, procurando "asegurar

26 Alexy, Robert, "Derechos fundamentales y estado constitucional democrático", en Carbonell, M. (ed.), Neoconstitucionalismo(s), Madrid, Trotta, 2003, p. 40.

27 Finnis, John, Ley natural y derechos naturales, cit., p. 379.

28 Ibidem, p. 302.

29 Ibidem, p. 134. Cfr. mi libro Perspectivas iusfilosóficas contemporáneas, cit., pp. 281-315. 
el conjunto total de condiciones materiales". ${ }^{30}$ Recordemos aquí la tradicional enseñanza de la escuela acerca que el derecho positivo no exige todo lo bueno ni prohíbe todo lo malo, pues su objeto es el buen vivir de la sociedad, por ende, lo que resulta prioritario es forjar con prudencia buenos ciudadanos y teniendo en cuenta el tenor moral de la sociedad en cuestión. ${ }^{31}$

Si se rechaza la razón práctica que puede brindar definiciones sobre el bien que debe buscar aquél que hace el derecho, por supuesto, hay que resignarse a la prescripción que se nos haga conocer, sin posibilidad de impugnar racionalmente lo mandado y descalificando toda queja al respecto por ser una pretensión "paternalista". En esa clave escéptica e iuspositivista extrema, los derechos humanos o cualquier juridicidad indisponible se convierte - parafraseando a Spaemann - en edictos de tolerancia de la autoridad, revocables según la voluntad de la misma cuando lo desee. Al hablar de racionalidad práctica en el momento creativo del derecho, incluimos exigencias de procedimiento o forma, pero también exigencias vinculadas al contenido de lo que se va a crear derecho. Es cierto que, así como a los planteamientos del tipo de Alexy les cuesta abrirse directamente a temas de racionalidad práctica sustanciales, por el lado de las versiones iusnaturalistas ha predominado tradicionalmente una atención en los contenidos más que en las formas y en los procedimientos.

\section{LA MORAL COMO ELEMENTO FAVORECEDOR DE LA MEJOR APLICACIÓN ${ }^{32}$ DEL DERECHO}

El siglo XIX y las facultades de derecho que copian las enseñanzas de la exégesis francesa definen que el trabajo del jurista consiste

$30 \quad$ Ibidem, p. 184.

31 "No es propio de la ley jurídica prohibir y castigar todos los juicios, sino sólo: 1) los más graves; 2) los que perjudican a los demás; 3) aquellos sin cuya prohibición la sociedad humana no podría mantenerse; 4) aquellos cuya prohibición ni acarree males mayores, y 5) todo ello ha de hacerse de modo gradual y progresivo teniendo en cuenta el tenor moral de la sociedad a la que debe aplicarse la ley" (Massini, Carlos I., El derecho natural y sus dimensiones actuales, Buenos Aires, Abaco, 1998, p. 99).

32 Reiteramos nuestras reservas para mantener la distinción entre creación y 
en identificar el caso genérico previsto en la norma legal donde se subsume el caso que atienden profesionalmente, y, a renglón seguido "desentrañar" el sentido de la misma mediante los métodos interpretativos, el que se constituirá en la premisa mayor que junto a la premisa menor o fáctica, permitirá obtener la conclusión del silogismo, que es la proyección individual de la solución legal. Un trabajo silogístico que excluye valoraciones o correcciones: "dura lex, sed lex", e incluso si el derecho es solo lo contenido en la ley y aparece un caso no previsto en la misma, cabe concluir - al menos en algunos integrantes de la exégesis francesa- que el caso es "no jurídico". La voluntad infalible es —en coherencia- incompatible con mecanismos de integración. Ya con Kelsen aquel saber teórico, lógico y aséptico de la aplicación queda absorbido por la voluntad, y lo declara expresamente: "el acto de interpretación no es de conocimiento sino de voluntad"; incluso por el camino de la cláusula alternativa clásica se disuelve la lógica de la pirámide jurídica.

Recordemos una distinción alexyana clave: las reglas jurídicas son "mandatos definitivos" (definen la conducta que el destinatario debe ejecutar para dar por cumplida la regla); mientras que los principios son "mandatos de optimización" (mandan la mejor conducta posible según las posibilidades fácticas y jurídicas). El mejor sistema jurídico debe contar con reglas y principios (también procedimientos que definan cómo se operan unas y otros), dado que éstos permiten resolver los cuatro problemas típicos que aquellas generan: i) indeterminación: al ser necesarias precisiones conceptuales y dejar márgenes para la elección del operador; ii) antinomias que exigen la elección de una; iii) lagunas que requieren ser integradas, y iv) solución prevista para el caso, pero extremamente injusta. Si bien las reglas se aplican por silogismos, los principios requieren de la técnica racional de la ponderación entre ellos, ella incluye: i) analizar si el medio previsto en la regla es idónea para el principio al que procura servir (regla de la idoneidad), ii) si no hay un medio menos restrictivo de principios e igualmente eficaz (regla de la necesidad);

aplicación del derecho dado que pensamos que siempre se dan en simultáneo esos trabajos jurídicos, pero lo mantenemos en este trabajo por su aceptación más generalizada. 
y iii) establecer las magnitudes de las afectaciones de principios y los consiguientes beneficios sobre los otros en tensión (regla de la ponderación en sentido estricto). Finalmente, la clave de bóveda alexyana es la "inextricable unión del discurso jurídico con el discurso práctico general”, que se concreta en la distinción entre la justificación interna y la justificación externa; aquella está controlada por la lógica y se dirige a garantizar el respeto de la "justicia formal"; y la externa reclama argumentos o razones que avalen o justifiquen las premisas que componen el razonamiento aplicativo. Frente a la propuesta de Dworkin de "one rigth answer", escoge Alexy la alternativa de la respuesta correcta simplemente como "idea regulativa", en el sentido que a veces se encuentra dicha respuesta correcta, aunque cabe siempre el esfuerzo por procurarla.

Es cierto que la terminología de la argumentación jurídica se ha generado en Europa continental, y es ajena a la tradición anglosajona que, por otra parte, nunca llegó a adherir a las enseñanzas exegéticas que proponían la interpretación como desentrañamiento o reconstrucción del pensamiento del legislador ínsito en la ley. Pero está claro que la agenda que acompaña a los promotores de la argumentación (por ejemplo, Manuel Atienza) tiene amplias coincidencias con tesis iusnaturalistas, aunque éstas aparecen remitidas y comprendidas dentro de la "prudencia jurídica". A ese respecto, recordemos que será Kant el que redefine abruptamente el significado de la prudencia excluyéndola del campo moral y conectándola con el interés o el egoísmo individual.

En la ética clásica:

La prudencia es la madre y el fundamento de las restantes virtudes cardinales: justicia, fortaleza y templanza; que, en consecuencia, solo aquel que es prudente puede ser, por añadidura, justo, fuerte y templado; $y$ que, si el hombre bueno, es tal, lo es merced a la prudencia. ${ }^{33}$

La definición heredada de Aristóteles de la frónesis o prudentia es: "disposición verdadera y práctica respecto de lo que es bueno y malo para el hombre"; ${ }^{44}$ y en esa sintonía Finnis la asimila directa-

33 Pieper, Josef, Las virtudes fundamentales, Madrid, RIALP, 1976, p. 33.

34 Aristóteles, Ética Nicomaquea, VI,5,1140 b 5. 
mente a la "sabiduría práctica" (uno de los "bienes humanos básicos"). Es obvio que ahí donde hay que discernir la conducta que se elige y prescribe se hace presente el juicio prudencial, y así concluye Kalinowski: "Hay tantos tipos de prudencia como sectores de la vida humana", ${ }^{35}$ consiguientemente Lachance afirma: "Declarar o definir el derecho pertenece a la prudencia". ${ }^{36}$ El origen mismo del derecho - como ha explicado Villey - se conecta con ese trabajo de los iurisprudentes de Roma que fueron haciendo iurisprudentia en los casos concretos. El juicio prudencial constituye una especie de puente entre aquellas exigencias generales, que por ejemplo establece la ley y las circunstancias contingentes de los problemas que corresponde resolver. La prudencia en cuanto "sabiduría del buen vivir" se forja por la experiencia y la memoria, por eso destacaba Aristóteles las dificultades de la prudencia entre jóvenes. Si bien la justicia del caso o equidad es la más bella de los tipos de justicia, ello no obsta para que tanto Aristóteles como Aquino ${ }^{37}$ defiendan que es mejor buenos legisladores a buenos jueces en tanto aquellos son menos cantidad, deben mirar muchos casos antes de regularlos y están distantes de las emociones que despiertan los sujetos concretos de un juicio, de todas maneras está en manos del juez el recurso a la excepción de la ley fundado en la equidad, aunque apoyándose en que de haber tenido en cuenta el legislador ese caso especial también hubiera contemplado la excepción. Frente a la discusión dworkiniana en torno a la respuesta correcta para cada caso, Finnis no duda en auspiciar cierta pluralidad de respuestas correctas, sin que la razón práctica pueda definir exactamente cuál es la mejor.

Con lo avanzado de lo explicado sobre la razón práctica o valorativa, parece obvio que si la rechazamos en la concreción del derecho, no quedan más opciones que acudir a la exactitud provista por la lógica formal o la alternativa de escoger según gustos o creencias subjetivas. Más aún, si no hay posibilidad de dar razones que ava-

35 Kalinowski, George, "Application du droit et prudence", Archiv für Rechts und Sozialphilosophie, L.III/2, Wiesbaden, 1967, p. 161.

36 Lachance. Louis, El concepto de derecho según Aristóteles y Santo Tomás, Buenos Aires, 1953, p. 121.

37 Cfr. Aquino, Tomas de, Suma Teológica I-II, q.95, a.1. 
len lo decidido, tampoco puede haber impugnaciones racionales que contradigan esas razones que se consideran erróneas. Otra consecuencia de ese escepticismo ético es que habría que renunciar a la alternativa de diálogos racionales, pues ellos sólo se limitarían a registrar opiniones que carecen de racionalidad objetiva. El poder y su ejercicio se legitima por la aceptación lograda por cualquier medio, y se suprime el camino de la justificación racional axiológica acerca de lo mandado.

\section{LA MORAL PARA EL MEJOR CONOCIMIENTO JURÍDICO}

El modelo epistemológico que sigue las enseñanzas de Descartes exige una "verdad clara y distinta". El iusnaturalismo racionalista y deductivista de los siglos XVII y XVIII se esfuerza por exhibir un sistema jurídico "more geométrico", con lo que resta es sólo positivizarlo por parte del legislador. Los razonamientos estudiados por Aristóteles como dialécticos y retóricos que parten de premisas plausibles o verosímiles, son desconocidos como proveedores de conocimiento por los promotores de la ciencia moderna. La ciencia exegética francesa se limita a glosar los códigos sin propuestas críticas o de lege ferenda, por eso Bugnet confesaba con orgullo: "Yo no enseño derecho civil, enseño Código de Napoleón". A ese cientificismo Kelsen le da una vuelta de tuerca y no duda en incluir en el prólogo de la primera edición de la Teoría pura del derecho que el propósito de la obra es elevar a la ciencia jurídica al rango de una verdadera ciencia cuyas proposiciones exhiban "objetividad y exactitud". Esa visión epistemológica tendrá un relevante respaldo con el Círculo de Viena cuando define que los caminos para conocer son dos: el de los juicios a posteriori o verificables, propios de la física o la química, y el de los juicios a priori o tautológicos, propios de la lógica o las matemáticas.

Con Alexy queda confirmada cierta pluralidad gnoseológica. En primer lugar, en el artículo "La naturaleza de la filosofía del derecho"38 el profesor alemán reconoce con ortodoxia kantiana que la filosofía

38 Alexy, Robert, “La naturaleza de la filosofía del derecho”, Doxa, núm. 26, 2003, pp. 145-160. 
es reflexión general y sistemática acerca de lo que existe (metafísica como ontología), o lo que debe hacerse o es bueno (ética), y cómo es posible el conocimiento de esas dos cosas (epistemología). A su vez la filosofía tiene tres dimensiones: normativa, analítica y sintética u holística, y la especificidad de la filosofía del derecho reside en su objeto: el derecho, de modo que aquellas preguntas y dimensiones le son propias. Finalmente, las preguntas iusfilosóficas se resumen en torno a la pregunta por la naturaleza del derecho: el concepto de norma y de sistema normativo, y el de la validez del derecho: real o fáctica (expedición autoritativa y eficacia social) e ideal o crítica (corrección o legitimidad o relación entre moral y derecho). Las propiedades necesarias o esenciales del derecho son: la coerción o fuerza, por un lado, y la corrección o rectitud, por el otro. Consignemos que Alexy no sólo ha sido profesor de filosofía del derecho sino también de derecho público, más aún, él ha hecho filosofía jurídica con material constitucional, y en éste terreno su propuesta se resume en un "constitucionalismo moderado" (entre "constitucionalismo" y "legalismo"); pero en su temprano libro de 1978 le reconocía a la ciencia jurídica seis funciones: ${ }^{39}$ estabilización, progreso, descarga, técnica, control y heurística, por ende, el científico que se ocupa del derecho está condenado a definir inicialmente si ese objeto es o no derecho, y esta pregunta remite a la validez y a la moral. Es procedente en el punto recordar que Alexy ha confesado que su libro de madurez ${ }^{40}$ es el "El concepto y la validez del derecho" de 1992 en tanto el problema asumido en el mismo debió haber sido el primero en resolver, sin embargo, su trayectoria académica comenzó con problemas jurídicos sectoriales como la argumentación jurídica o los derechos fundamentales. Pero no solo hay una iusfilosofía y una ciencia jurídica alexyana, sino un saber jurídico resolutorio o aplicativo que está confiado a la razón práctica o ética en tanto apela a ella para discernir lo que es y no es derecho, como también para encontrar la mejor respuesta jurídica para el caso, especialmente cuando hay

39 Alexy, Robert, Teoría de la argumentación jurídica, cit., p. 255.

40 Alexy, Robert, "Algunas reflexiones en torno a cómo mi pensamiento jurídico ha ido desarrollándose con el paso de los años", en Bernal Pulido, Carlos (ed.), La doble naturaleza del derecho, Lima, Palestra, 2011. 
que recurrir al contenido moral de los principios y a su ponderación racional.

La tríada gnoseológica aludida en referencia a Alexy, por supuesto que es igualmente promovida por la perspectiva aristótelica-tomista. ${ }^{41}$ Aunque quizá habría que hacer una doble precisión; por un lado, que la noción de ciencia jurídica, llamada sorprendemente: dogmática, cuesta proyectarla al mundo anglosajón como la conocemos en la cultura continental europea; y, por otro lado, en la tradición iusnaturalista hay voces que dudan del nivel propio y diferenciado de la ciencia jurídica (por ejemplo, Villey). De todas maneras, nos inclinamos por reconocer en primer lugar la posibilidad y necesidad de una filosofía jurídica que asuma: i) el problema ontológico o conceptual del derecho; ii) el problema gnoseológico jurídico, abocado a conocer las características y tipos de saberes jurídicos; iii) el problema lógico jurídico, o sea, las estructuras lógicas que reconocemos en el derecho, y iv) el problema axiológico referido al valor del derecho. Destaquemos que las respuestas centrales a esa respuesta remiten a un saber práctico que ubica el derecho en el campo de las conductas sociales a las que regula y valora en coherencia con las exigencias del bien común, pero dicho saber jurídico desde esa universalidad iusfilosófica, debe transitar hacia la ciencia jurídica cuyo objeto son los derechos vigentes y válidos en orden a su descripción, interpretación, sistematización y valoración; y concluir en la resolución prudencial y justa de los casos concretos en el marco institucional respectivo. Sin perjuicio de lo consignado en relación a la teoría jurídica típicamente anglosajona, recuperemos algunas tesis conectadas al tema que hacemos propias: i) "Los criterios decisivos, en última instancia, para la formación de conceptos en la ciencia social, son los estándares de razonabilidad práctica irrestrictamente racionales, de recto juicio acerca de qué hacer y de qué no hacer"; 42 ii) Finnis adhiere al "punto de vista interno" propuesto por Hart, pero lo corrige en tanto lo asimila al punto de moral o de razo-

41 Cfr. Martínez Doral José M. "La estructura del conocimiento jurídico”, EUNSA, Pamplona, 1963

42 Finnis John, Aquinas. Moral, Political and Legal Philosophy, Oxford, Oxford University Press, 1998, p. 51. 
nabilidad práctica adoptado por "los intereses y la comprensión del hombre maduro y razonable" 43 (del spoudaios o phronimos); iii) el recurso a la "analogía" que permite distinguir en los asuntos humanos lo refinado de lo primitivo, el buen ejemplar del caso desviado, lo que se dice sin restricciones o de modo absoluto a lo que se dice en algún sentido o de algún modo; iv) no se rechazan las descripciones pero sólo con las valoraciones ellas son realmente iluminadoras y significativas, y v) hay una cierta coincidencia entre Finnis y Alexy respecto a la doble naturaleza del derecho, ${ }^{44}$ es decir, la validez real, institucional, social o autoritativa y la validez crítica, valorativa, ideal o racional.

Mantener la inercia cientificista y negadora del saber práctico trae como primera consecuencia, empobrecer el conocimiento jurídico impidiendo que asuma un rol crítico y valorativo o justificatorio. Nino a partir del análisis de los modelos epistemológicos de Kelsen, Ross, Bulygin y Alchourrón ha denunciado las limitaciones de esa ciencia jurídica que se abstiene de hacer propuestas lege ferenda, y de responder la pregunta central para el ciudadano sobre si está racionalmente obligado a cumplir lo dispuesto por las normas jurídicas positivas. ${ }^{45}$ Sin la dimensión moral o axiológica el derecho queda reducido a voluntarismo decisionista o mero ejercicio de poder coercitivo. Solo desde la pluralidad gnoseológica enriquecemos el conocimiento del derecho y, consiguientemente, podemos justificarlo, mejorarlo o esclarecerlo. Ni filosofismo, ni cientificismo, ni casuismo, más bien unidad del saber jurídico que no excluye los acentos y las vocaciones personales en el ejercicio profesional.

43 Finnis, John, Ley natural y derechos naturales, cit., p. 49.

44 Cfr. Massini-Correas, Carlos I., Jurisprudencia analítica y derecho natural, Madrid, Marcial Pons, 2019, p. 34.

45 Calsamaglia recepta de Nino que el teorema fundamental de la teoría jurídica contemporánea es "porque debo obedecer el derecho" y esta pregunta "no puede responderse con descripciones, a no ser que tomemos las descripciones como prescripciones, y eso requiere un juicio moral" (Calsamiglia, A., "Teoría del participante versus teoría general del Derecho: una aproximación", Anuario de Filosofía del Derecho, t. XIII y XIV (1996-1997), Madrid, p. 487. Es conocida la tesis de Carlos Nino de que la justificación jurídica desemboca en justificación moral (cfr. Derecho, Moral y Política, Barcelona, Ariel, 1994, cap. 2). 


\section{LA MORAL PERSONAL COMO LÍMITE AL CUMPLIMIENTO DE LA NORMA JURÍDICA}

La reducción del derecho a la ley, el deslinde del derecho con la moral, la soberanía estatal, la Constitución como un programa político dirigido al legislador o el escepticismo ético son un combo que no deja pie para imaginarnos la posibilidad de incumplir la ley invocando mi conciencia ética y el daño que me generaría. Esa alternativa sólo podría consagrarse si el legislador lo dispone expresamente, pero el eventual costo que generaría esa concesión a la seguridad jurídica, sería absolutamente intolerable para el EDL. En la visión de Kelsen el contenido de lo prescrito por la norma jurídica resultaba irrelevante, dado que el deber jurídico coincidía exactamente con la conducta contraria a la prescrita, y, en consecuencia, la coerción dispuesta por el derecho sin ningún posible cuestionamiento racional, era la consecuencia hipotética prevista para los que incurrían en alguna conducta contemplada como supuesto fáctico de la norma. Coherentemente Kelsen desde su voluntarismo e irracionalismo axiológico, asumía también el rechazo de una imposible seguridad jurídica en tanto se la identificara con previsibilidad, por ello a esa aspiración la calificaba como una "ficción".

Explícitamente Alexy reconoce que "la moral puede estar vinculada con el derecho positivo, en primer lugar, a través de la inclusión de principios y argumentos morales en el derecho; en segundo lugar, por medio de que el contenido posible del derecho sea delimitado por la moral, y, en tercer lugar, porque la moral fundamente un deber de obediencia al derecho", ${ }^{46}$ y respecto a ésta última conexión precisa el profesor de Kiel: "Solo los que conceden prioridad absoluta al valor moral de la seguridad jurídica no podrán admitir nunca que el deber moral general de obediencia al derecho pueda retroceder por razones morales. Todos los demás tienen arduos dilemas morales que resolver caso por caso", ${ }^{47}$ aunque reconoce que la clausula que "la injusticia extrema no es derecho" permite a los no

46 Alexy, Robert, "Derecho y Moral”, en La institucionalización de la justicia, Granada, Comares, 2016, p. 18.

47 Ibidem, p. 23. 
positivistas resolver los casos más graves y notorios. Carlos Nino sobre la obligación de obedecer al derecho, parte de la tesis que "el sistema jurídico - con las autoridades y sanciones que le son inherentes- se justifica en tanto y en cuanto él es un medio necesario para preservar y promover derechos humanos",48 y prestando atención a los casos de un derecho democrático, distingue entre la situación del juez (u otro funcionario) y la del súbdito, para luego considerar la posición moral de un juez frente a un súbdito que se ha considerado moralmente facultado a desobedecer el derecho. Al margen las sutiles distinciones del profesor argentino, lo que interesa destacar es que no suscribe ninguna obligación absoluta de obedecer al derecho, y reconoce tanto la "objeción de conciencia" (opera cuando un individuo cree que una obligación jurídica está en conflicto con sus principios morales o religiosos) como la "desobediencia civil" (consiste en la inobservancia de normas jurídicas que se consideran injustas con el propósito de modificarlas).

Pasando a autores iusnaturalistas clásicos que no dudan en respaldar a los derechos humanos, recordemos que en Finnis el significado focal de autoridad queda vinculado - en terminología tomada de Raz- a "razón excluyente", es decir, "como razones suficientes para actuar a pesar de que el súbdito no habría adoptado la misma disposición",49 y reconoce la obligación moral prima facie de obedecer al derecho y que las reglas jurídicas gozan de "fuerza excluyente". El profesor de Oxford entiende que la proposición que "la ley que es defectuosa en su racionalidad es solo en un sentido diluido", no se ofrece "como aplicable inmediatamente es un tribunal de justicia (o en otro contexto intrasistemático)"; ${ }^{50}$ de todos modos concluye que "la objeción de conciencia no es un principio o fundamento generalmente válido para eximirse de la ley".51 Más allá de la opinión de Finnis, estimamos que un complemento ineludible del análisis de la ley injusta es el derecho a la objeción de conciencia que cubre cierto incumplimiento de la norma jurídica en función de razones mora-

51 Ibidem, p. 317. 
les racionales que puede invocar su destinatario. Ese derecho, cubre los reparos razonables del ciudadano o funcionario frente a la violencia moral que le provoca la prescripción en cuestión, y así el derecho como institución se pone al servicio de un auténtico bien común que incluye los bienes personales. Para el iusnaturalismo clásico no puede haber dudas del valor racional o moral — también específicamente jurídico- que corresponde asignarle a la conciencia de aquel que debe obedecer a la ley. ${ }^{52}$ Una manifestación de ese respeto al destinatario por sobre ficciones impuestas por el iuspositivismo legalista, puede ser que ya Tomás de Aquino justificaba a aquél que incumplía la ley por ignorancia no culpable dado que la ignorancia convertía al acto en involuntario, ${ }^{53}$ y también la eximición de pena cuando la involuntariedad es total o se disminuye la pena cuando hay una voluntariedad disminuida por flaqueza o pasión. ${ }^{54}$ Es que, si la ley es dictamen de la razón práctica y está al servicio del hombre, no parece razonable que no se conceda autorización para no cumplir la norma a aquel que, sin generar daños significativos o irreparables, aduce el perjuicio moral íntimo que le provoca ese acatamiento.

Si se avala la asunción sincera de alguna moral racional por parte de un ciudadano que la invoca para no cumplir una norma, y puede concluirse que la excepción solicitada no trae mayores inconvenientes al bien común, resultará muy difícil en términos racionales concluir el rechazo de esa autorización, quizás solo haya que atribuirla a prejuicios ideológicos o dogmatismos irracionales. Por supuesto que la clave es el pedido basado en una moral racional, y este previo análisis puede provocar justificadamente su rechazo. En efecto, concederemos no forzar la transfusión de sangre a un Testigo de Jehová, pero no la aceptaremos si aduce que le da repugnancia la sangre o que le recuerda a los vampiros; o rechazaremos el planteamiento de un imputado de haber matado a un policía, que dice pertenecer a una religión en la que esos actos son premiados con la vida eterna.

52 Cfr. Portela, Jorge Guillermo, La justificación iusnaturalista de la desobediencia civil y de la objeción de conciencia, Buenos Aires, EDUCA, 2005.

53 Aquino, Tomas de, Quodlibetum, 1,9,3.

54 Aquino, Tomas de, Suma Teológica, I-II, q,105, a.2 
Claro está, que, si todo el campo de la moral se remite a lo irracional o a las puras creencias subjetivas, se torna imposible habilitar un derecho de objeción de conciencia porque en su apoyo pueden venir tesis absolutamente absurdas, gravemente dañinas o peligrosas.

\section{LA MORAL COMO FACILITADORA DE LA EFICACIA ${ }^{55}$ DE LA NORMA JURÍDICA}

El racionalismo que animaba el proceso de codificación no toleraba ninguna fuerza de la realidad social capaz de constituir derecho, éste sólo se generaba en la voluntad del legislador y la realidad se acomodaría a la misma. Concluye Liborio Hierro: "La Codificación, fiel en términos generales al pensamiento ilustrado, trató de poner fin al debate sobre la fuerza normativa de la costumbre contra ley o del desuso con una clara decisión normativa en contra de ambos". ${ }^{56}$ Un ejemplo relevante de esa matriz es el referido a la costumbre, y así los códigos, como por ejemplo el de Vélez Sarsfield, la rechaza cuando contradecía a la ley, y la toleraba como supletoria o interpretativa. El universalismo de aquellos tiempos del EDL postula con entusiasmo la utilidad de los códigos europeos para todos los pueblos del mundo; más aún, no hay otro protagonista que el "individuo" y sus derechos naturales que se reducen a "libertad, propiedad, seguridad y resistencia a la opresión" (artículo 2 de la Declaración Universal de los Derechos del Hombre y del Ciudadano de 1789). Con Kelsen ya no interesa el fin ni el contenido de las normas, y en el sistema jurídico sólo se aceptan normas jurídicas, no principios ni derechos humanos. La teoría "pura" reduce las normas a juicios hipotéticos y descarta cualquier referencia a realidades sociales, aunque compute un mínimo de eficacia para la existencia del derecho; pues esta apertura a la realidad le generó fuertes críticas denunciando incoherencias graves. Por supuesto que esa cultura jurídica

55 La eficacia jurídica puede entenderse de distintas maneras, Liborio Hierro distingue hasta siete modos que termina agrupando en tres típicos: cumplimiento, aplicación y éxito (Cfr. La eficacia de las normas jurídicas, México, Fontamara, 2010). Aquí la entenderemos como cumplimiento voluntario de la norma jurídica.

56 Ibidem, p. 50. 
tiene muy poco ver con la que anima al common law en donde siempre el derecho estuvo ligado a los casos y a las costumbres. Pero en aquella mirada del iuspositivismo tradicional y su obsesión por la ciencia, la clave es la sinonimia entre derecho y ley o derecho y normas positivas.

Parece comprensible sostener que resulta muy complicado en el marco de una filosofía jurídica kantiana la apelación a la realidad y a la necesidad de conformar a la misma el aparato conceptual que se construya. Más bien, lo que se impone es ideas o modelos contrafácticos que orienten a la realidad, aunque nunca se los alcance, y un ejemplo difundido de esas construcciones puede ser la metáfora de Rudolf Stammler de considerar la justicia como la estrella polar que guía al navegante, sin posibilidad de llegar a la misma. Pensamos que ha sido Etienne Gilson uno de los filosófos que con mayor claridad y contundencia planteó que una de las primeras alternativas que se le presentan al filósofo es si va a seguir un camino realista (nutrido por Aristóteles y Aquino) u otro idealista (configurado por Descartes y Kant); sintéticamente: ${ }^{57}$ i) el realista partirá del ser, incluyendo en él el pensar, donde las ideas son conceptos abstraídos de las cosas, la epistemología se ajusta a la ontología, y ii) el idealista partirá del pensar, incluyendo en él al ser, las ideas son los modelos a los que debe ajustarse la realidad, o mejor, la realidad misma; de la epistemología se saca la ontología. Nos parece que la iusfilosofía alexyana enfrenta esos riesgos de idealismo, más allá de nuestra coincidencia con muchas de las tesis jurídicas que propone, aunque nuestra fundamentación de ellas difiera. Un ejemplo de ese método idealista que inspira a Alexy es nada menos que su pieza central del dialogo racional contrafáctico de donde nace el derecho, que conlleva la prevención kantiana que nadie podrá llevar a cabo uno que respete todas sus exigencias de manera absoluta. Algo parecido podemos ver en algunos trabajos alexyanos, me detendré en el titulado "Justicia como corrección" porque ahí leemos:

La justicia es corrección en la distribución y en la compensación. Esta definición tiene, a primera vista, una desventaja: es abstracta, privada

57 Cfr. Gilson, Etienne, El realismo metódico, Madrid, Rialp, 1963. 
de contenido. En ella, el concepto de justicia, abstracto e indeterminado, es sustituido por un segundo concepto, el de corrección, más abstracto aún e indeterminado que el primero. Y es justamente la mayor abstracción del concepto de corrección lo que hace posible un análisis satisfactorio del concepto de justicia. ${ }^{58}$

Sin perjuicio de esa matriz idealista, también en ese artículo aparecen apelaciones que van más allá de formas o estructuras contrafácticas universales, así se invocan: "los intereses y las necesidades, además de la tradición y la cultura, de los individuos implicados", 59 la necesidad de la institucionalización y la Constitución, etcétera. Conocida es la denuncia por incurrir en "falacia procedimental" que se hace a las visiones procedimentalistas o formalistas, que, sin embargo, concluyen definiciones sustanciales o materiales.

Es obvio que el realismo referido en la obra de Gilson, es asumido explícita y completamente en la filosofía jurídica clásica. Expresamente Aquino reconoce que "a los hombres de bien se les induce más eficazmente a la virtud recurriendo a la persuasión que a la coacción", ${ }^{60}$ ratificando en la cuestión 95, artículo 3, que "el fin de la ley humana es la utilidad de los hombres" y que para ser justa debe ser "posible según la naturaleza y las costumbres del país, proporcionada a los lugares y a los tiempos", pero "la disciplina debe acomodarse a cada uno según sus posibilidades, incluidas las naturales (pues no se pide lo mismo a un niño que a un hombre maduro),y según las costumbres sociales". También recordemos que la ley no prohíbe todo lo que está mal porque "debe permitirse a los hombres imperfectos en la virtud muchas cosas que no se podrían tolerar en los hombres virtuosos", ${ }^{61}$ y "la costumbre ayuda mucho a la observancia de la ley" y lo que se hace contra ella "parece más pesado", ${ }^{62}$

58 Alexy, Robert, “La justicia como corrección”, Doxa, núm. 26, 2003, p. 163.

59 Ibidem, p. 165.

60 Tomas De Aquino, "Suma Teológica”, I-II, q.95, a.1.

61 Ibidem, I-II, q,96, a.2.

62 Ibidem, q.97 a.2. 
por eso es "difícil cambiar las costumbres del pueblo", 63 e incluso "la costumbre tiene fuerza de ley, deroga la ley e interpreta la ley". ${ }^{64}$

MacCormick y Weimberger advierten que "el jurista tiene que plantearse también cuestiones que se refieren a la existencia social del derecho, su forma de operar en la sociedad y las relaciones entre el derecho y la sociedad", ${ }^{65} \mathrm{y}$ en ese interés debe tenerse en cuenta el ethos social dado que el ayudará al éxito de la norma jurídica. Aunque insistamos que no cualquier moral social es compatible con la moral racional o con el respeto de los derechos humanos, aunque si el jurista no suscribe la posibilidad de esa confrontación dado que niega la existencia de una moral racional, el riesgo es que termine postulando un derecho que será resistido por la sociedad y que solo deberá recurrir a la coerción para conseguir su seguimiento, quedando abortada la alternativa del cumplimiento voluntario. En sintonía con la ética clásica repitamos que lo mejor puede ser enemigo de lo bueno, de manera que el objeto de la prudencia es escoger la mejor opción dentro de aquellas que resultan posibles.

\section{LA MORAL COMO COMPLEMENTO DE LA COERCIÓN JURÍDICA}

Hasta aquí hemos hablado de la eficacia del derecho en tanto cumplimiento voluntario de la norma, lo cual favorece el efecto pedagógico que se propone y evita los costos de su incumplimiento, pero hay otra conexión que se comprueba hoy de la moral racional con el derecho a la que queremos aludir. Se trata de que pareciera que el derecho ha dejado de confiar solamente en la coacción, y se orienta a incorporar medios que apelan a la conciencia ética y la intención del ciudadano. Aquí también hay otra distancia con el common law en donde son visibles los entrecruzamientos entre el derecho y la moral, pensemos en la relevancia jurídica que se le otorga a la mentira, que equivale a obstrucción de la justicia. Frente a ello, recordemos

63 Ibidem, q.97 a.3.

64 Idem.

65 Maccormick, Neil y Weinberger, Otta, An Institutional Theory of Law, Dordrecht, D. Reidel,1986, p. 45. 
que para Kelsen el derecho se reduce a técnica coercitiva para dirigir conductas, y textualmente escribe: "Decir que un orden jurídico es eficaz significa simplemente que la conducta del agente se ajusta a dicho orden". ${ }^{66}$ En la teoría pura las normas jurídicas se dirigen al juez quien era el que las aplicaba como titular de la coerción, y el derecho subjetivo coincidía con el reclamo al juez para que proceda coercitivamente. Es elocuente al respecto el testimonio del Bobbio post-kelseniano de 1971 con su "teoría funcional" y la recuperación de la pregunta acerca del "para qué sirve el derecho": "común a toda la corriente del positivismo jurídico desde Austin hasta Ihering y Kelsen, (es) aquella según la cual el Derecho obtiene su fin (que es esencialmente represivo) a través de la organización de sanciones negativas (el Derecho como aparato coactivo)". ${ }^{67}$

Es constitutivo a todo pueblo contar con un cierto ethos desde el cual se juzgan como valiosas o disvaliosas conductas, hábitos, instituciones o normas. Pero lo que está en juego es preguntar si esa particular moral social es o no compatible con la moral racional mínima y objetiva, que justifica o descalifica exigencias positivas o negativas. Torturar está siempre mal, una sociedad de castas carece de respaldo racional objetivo, impedir a una mujer que se presente a elección por el solo hecho de ser mujer es irracional, las cárceles secretas son un disparate jurídico, es violencia irracional obligar a que alguien se vista conforme a cierta moda si quiere acceder a tribunales, etcétera; esos son todos ejemplos de injusticia, irracionalidad e inmoralidades que acompañan a la sociedad, pero ese seguimiento social no transforma en legítimo,valioso o racional lo que objetivamente no lo es. Aquel ethos social también puede ser un factor que facilite el cumplimiento voluntario, y la consideración de este elemento debe ser considerado por la prudencia de aquellos que hacen el derecho. Es obvio que ésta conclusión sólo puede ser respaldada por los que suscriben la existencia de una moral racional.

En el derecho actual se observa una serie de esfuerzos destinados a conseguir fines razonables deseables, pero no sólo a través de la

66 Kelsen, Hans, Teoría pura del derecho, México, Porrúa, 2000, p. 70.

67 Bobbio, Norberto, "La función promocional del derecho", en Bobbio, Norberto, Contribución a la teoría del derecho, Fernández Torres eds., 1980, p. 368. 
coerción o la imposición de penas y perjuicios para aquel que no se comportó conforme a la pretensión contenida en las normas. En ese proceso variado y creciente de desjudicialización y hasta desjuridización de problemas sociales, ocupan un lugar destacado los "medios alternativos de solución de conflictos" que procuran resolverlos no por medios típicos, formales, estructurados y judiciales. Puede sorprender que el mismo Aquinate avaló el recurso a árbitros para resolver casos: "En asuntos humanos, unas personas por propia voluntad pueden someterse al juicio de otras, aunque éstas no sean sus superiores, como acontece en los que se comprometen a la decisión de árbitros", ${ }^{68}$ y cuando afirma la viabilidad de perdón por parte del acusador al ofensor, como por ejemplo en caso de injuria. ${ }^{69}$

Otro ejemplo puede ser la "justicia transicional" implementada en sociedades políticas que han experimentado violaciones masivas de derechos humanos, y procuran instalar democracias verdaderas. También reflejan una matriz no coercitivista la "justicia restaurativa"70 u otros nombres equivalentes como: reparativa, restitutiva, reintegrativa, comunitaria, consensual, solidaria, etcétera. En ella lo que se busca es comprometer en la solución de los problemas jurídicos a la sociedad, a las víctimas y a las familias, a los fines de lograr la reconciliación o restauración de las relaciones que han quedado dañadas por la ofensa o el ilícito. Lo importante aquí no es generar la consecuencia dañosa sobre el ofensor de acuerdo a lo que está previsto normativamente para la conducta, sino la preocupación se orienta hacia adelante, en aras de conseguir el compromiso sincero y voluntario para no volver a ofender al ciudadano. El juez, la policía, el proceso y la sanción pasan a un segundo plano y el protagonismo lo adquieren la víctima y el ofensor, en cuyas manos se pone en buena medida la solución del conflicto en prospectiva. Lo decisivo pasa a instalarse en el plano moral, lo que importa es el arrepentimiento y el compromiso de comportarse como el "buen vivir ciudadano" lo exige. De ese modo el derecho deja de mirar para

68 Aquino, Tomas de, Suma Teológica, I-II, q.67, a,1.

69 Ibidem, I-II, q.67, a,4.

70 Kemelmajer de Carlucci, Aída, Justicia restaurativa, Santa Fe, Rubinzal-Culzoni, 2009. 
atrás en aras de identificar conductas antijurídicas a las que les corresponde aplicar la sanción jurídica prevista en las normas, y se carga de preocupación por la persona en su integralidad, aunque especialmente mira su disposición futura para no volver a cometer una falta. Ese cambio de perspectiva supone que la reacción frente al delito, daño u ofensa, asume dimensiones estricta o típicamente morales o éticas en donde la interioridad, la voluntariedad, el entorno social y características propias de la persona se tornan mucho más importantes que la sanción.

A fines de la década de los sesenta Bobbio publica un artículo titulado "La función promocional del derecho" en donde llama la atención acerca de la aparición en el Estado social contemporáneo de nuevas técnicas de control social, no ya centradas en el desalentamiento de ciertas conductas sino en el alentamiento; poniendo en crisis las teorías tradicionales del derecho que consideran al derecho exclusivamente en su función represiva o protectora, y abriendo paso al estudio de la "función promocional" del derecho. En plena sintonía con esa nueva perspectiva del derecho recurriendo a medios no coercitivos, traigamos a colación la jurisprudencia de la Corte Interamericana de Derechos Humanos en donde abundan ejemplos en que la condena incluye medidas no coercitivas y reparadoras en términos morales, tales como: pedidos de disculpas, arrepentimientos, homenajes, construcción de monumentos, cursos de capacitación, etcétera.

Aquella típica y kantiana ruptura entre el derecho y la moral sin relevancia para la vida social, implicaba que, para conseguir el cumplimiento del derecho, que era a su vez el único límite a la libertad, bastaba la amenaza de la sanción respaldada por la coerción estatal. Pero hoy queda claro que la ley y la amenaza estatal no basta, ella requiere de cierta voluntariedad y mensajes que procuran enseñar y alentar comportamientos futuros. Sin embargo, si la moral queda totalmente librada a la irracionalidad o a la subjetividad aquellos esfuerzos carecen de justificación. El derecho quiere también educar sobre lo que está objetivamente bien y lo que cabe de arrepentimiento para no reiterar lo que está mal. 
El modelo epistemológico que se impone en las universidades europeas en el XIX promueve cierto autismo de las ciencias, y ello queda reflejado en las facultades de derecho "insulares" donde se rompen todos los puentes con otros saberes. Más aún, cada una de las materias de la respectiva curricula se constituyen en unidades autosuficientes creando hasta el aparato conceptual y lingüístico que se utilizará en ellas. Las ciencias jurídicas, de manera elocuente pasan a ser "dogmáticas", y ello supone verdades reveladas que se aceptan y no se discuten racionalmente. Todo el derecho está en la ley - para la exégesis francesa- o en las normas coercitivas - para Kelsen-, de manera que el jurista no necesita, mejor dicho, no debe ir más allá de ellas si procura mantenerse en el terreno científico. Sobre todo, se rompe el contacto con la moral, la política, la economía, la cultura, etcétera, y por esa vía se pierde el "sentido" del derecho o el "para qué". Una vez más recordemos al Bobbio de la teoría funcional del derecho cuando en el Prólogo "Dalla Estructura Alla Funzione" afirma: "El paso de la teoría estructural a la teoría funcional es también el paso de una teoría formal (o ipura! a una teoría sociológica (¿impura?)... se oye que la sociología llama a la puerta", ${ }^{71}$ y en otro trabajo confirma: "lo que caracteriza el actual momento del estudio del derecho es el hecho de que los juristas están saliendo de su esplendoroso aislamiento". ${ }^{72}$

La superación de aquel aislamiento promovido y funcional al EDL se constata al nivel del derecho ya creado, como en relación a su aplicación a los casos. Lo sabemos desde Aristóteles que el derecho es inescindiblemente social y político, y consiguientemente moral. Como señalamos arriba la presencia de la racionalidad práctica en el derecho implica que no es posible postular que no haya conexiones con la moral y la política. De una manera muy sólida y omnicomprensiva Alexy, con su tesis del discurso jurídico como caso especial

71 Bobbio, Norberto, Dalla struttura alla funciones, Milán, Edizioni di Comunitá, 1984, p. 9.

72 Bobbio, Norberto, “Derecho y ciencias sociales”, en Bobbio, Norberto, Contribución..., cit. p. 225. 
del discurso práctico general, pone de relieve la apertura del mundo jurídico al hombre en su integralidad y su razonabilidad práctica con sus distintas dimensiones. Advierte el profesor de Kiel que

las reglas del discurso, sin embargo, no definen una forma particular de vida, sino algo que es común a toda forma de vida humana, sin perjuicio del hecho de que en ella se imponen en diferente medida. La teoría del discurso rastrea de ese modo en el potencial racional existente en la realidad humana. Ella persigue en este sentido ilustración sobre la naturaleza del hombre y se encuentra en eso, pero solamente en eso, en la tradición del derecho natural... La teoría del discurso permite en efecto no sólo una fundamentación de los derechos fundamentales y los derechos humanos, ella se evidencia también como teoría básica del estado constitucional democrático. ${ }^{73}$

La teoría herculeana de la interpretación jurídica de Dworkin confirma que "cualquier teoría del derecho comprensiva debe ser ella misma un ejercicio de teoría moral y política normativa... los problemas de jurisprudencia son, en lo más profundo, problemas de principios morales, no de hechos legales ni de estrategia". ${ }^{74}$

La filosofía jurídica de Finnis está fuertemente penetrada por la filosofía política y la moral. En efecto, aquella gira en torno a los valores básicos o formas básicas del bien (vida, conocimiento, juego, amistad, experiencia estética, razonabilidad práctica y religiosidad) que la razonabilidad práctica procura a instancias de su primer principio: "ha de hacerse y procurarse el bien". Respecto a los derechos naturales o morales o humanos, ellos "expresan virtualmente todas las exigencias de la razonabilidad práctica", ${ }^{75} \mathrm{y}$ destaca el profesor de Oxford entre estas últimas el "procurar el bien común de las comunidades propias" y que "La persona humana debe buscar realizar y respetar los bienes humanos no simplemente en sí misma y en su propio beneficio, sino también en común, en comunidad". ${ }^{76}$ Atento a

73 Alexy, Robert, Teoría del discurso y derechos humanos, Bogotá, Universidad Externado de Colombia, 1995, p. 136.

74 Dworkin, Ronald, Los derechos en serio, Barcelona, Ariel, 1984, p. 51.

75 Finnis, John, Ley natural y derechos naturales, cit., p. 227.

76 Ibidem, p. 191. 
que el derecho "sin restricciones" es el de una comunidad completa o política, admite el profesor de Oxford que el "bien común" se conecta en su significación con las fórmulas "interés público" o "bienestar general". 77

Parece forzoso que si el jurista se interesa por el bien humano -individual o común - le queda clausurada la alternativa del autismo jurídico. Y los derechos humanos o los principios jurídicos protegiendo bienes individuales o colectivos- remiten explícita e inexorablemente a la moral y a la política. Pero esa superación del juridicismo también se comprueba en el ámbito de los casos que necesitan ser resueltos por los jueces, y en ese terreno frente a los "deniers" o "veriphobics" — como los llama Michele Taruffo- corresponde insistir con el maestro italiano que "la verdad es condición de la justicia” y que no hay dos verdades (la procesal o formal y la real o material), sino una, conforme a la teoría de la "correspondencia".78 Recordemos que en la jurisprudencia de la Corte Interamericana de Derechos Humanos se ha hablado sobre el efecto "reparador" que tiene la verdad y también de un "derecho a la verdad". En ese campo veritativo en torno a los hechos que se discuten, tienen creciente importancia los saberes no jurídicos que le proporcionan al juez los peritos informando desde: ciencias duras (por ejemplo, química), blandas (por ejemplo, sicología), pseudo ciencias (por ejemplo, grafología) y ciencias basuras (por ejemplo, astrología). Los hechos tienen una relevancia jurídica en sí mismos, más allá incluso de la que precisan las normas jurídicas, y ejemplos de esa índole abundan en la jurisprudencia argentina: cosa juzgada írrita, abuso del derecho, plazo de gracia, gravedad institucional, emergencia económica, etc. Sin embargo, la enseñanza del grado sigue mayoritariamente impregnada de la inercia juridicista y totalmente ajena a saberes no jurídicos. Por supuesto que no se pretende que el abogado reemplace al perito, pero sí que tenga la información mínima necesaria como para establecer la eficacia probatoria de las pericias. En la cultura jurídica del common law donde el derecho se construye prin-

77 Ibidem, p. 184.

78 Cfr. Taruffo, Michele, La prueba, Madrid, Marcial Pons, 2008 y Verdad, Justicia y Derecho, Buenos Aires, Astrea, 2020. 
cipalmente por los jueces y desde los casos, la relevancia del conocimiento de los hechos explica precisiones como las que brinda la Corte Suprema de Estados Unidos en fallos como "Daubert v. Merrell Dow Pharmaceuticals Inc." de 1993.

Un jurista que comprenda el sentido del derecho y la relevancia e inalienabilidad de los derechos, seguramente no permanecerá con una mirada ceñida estrictamente a lo que dicen las normas. Por supuesto que no estamos despreciando la seguridad jurídica y el valor de las normas, sino reivindicando los límites para que se les reconozca como válidas y obligatorias, y en esos márgenes escoger la mejor respuesta, es decir, la más justa. La verdad proporcionada por los saberes teóricos y los saberes prácticos tiene un valor epistemológico (identifica el error), moral (discierne el bien), político (los dictadores prefieren la manipulación) y jurídico (equivale a lo justo). Convertir al derecho en un fin en sí mismo conlleva una distorsión que nos impide elegir al mejor derecho de aquel disvalioso. No está de más recordar que lo que justifica al derecho es mejorar la buena vida social en la que está toda la sociedad implicada. No hay posibilidad de justicia y buen vivir sin superar el juridicismo y reencontrarse con el bien del hombre.

\section{LA MORAL DEL OPERADOR JURÍDICO PARA EL MEJOR DERECHO}

En el marco del EDL y del iuspositivismo decimonónico funcional al mismo, estaba claro que resultaba irrelevante la calidad moral del operador del derecho, pues todos estaban para "decir el derecho" que coincidía exactamente con el contenido de una ley hecha por la voluntad infalible del legislador, que como tal no se contradecía, era clara, no redundante, siempre justa, etcétera. Esa consigna profesional -iuris dictio - valía para el que la enseñaba, asesoraba a los clientes, abogaba ante las autoridades o la aplicaba a los casos con imperium. Destaquemos la función judicial recordando una vez a Montesquieu y su caracterización del juez como "ser inanimado" y "bouche de la loi". La única idoneidad requerida para ser juez era la científica, y las demás (ética, aplicativa o prudencial, sicológica, física, y gerencial o administrativa) resultaban irrelevantes, dado que, 
si se apartaba de la única función para la que se le había otorgado poder, es decir, proyectar silogística y mecánicamente para el caso el sentido contenido en la ley, cometería el delito de prevaricato y se lo destituiría. En el caso de Kelsen, a tenor de su escepticismo axiológico, el voluntarismo judicial no podía ser controlado, y así el juez elegía de manera irracional o no cognoscitivamente la decisión que adoptaba.

Es indudable cuánto ha potenciado el EDC el poder y la discrecionalidad judicial, y ello se revela en las diferentes líneas jurisprudenciales y en las mayorías y minorías de los tribunales. Es cierto que en el Common Law la importancia de la personalidad ética de los candidatos siempre ha sido una variable decisiva en la elección de los jueces, y una muestra — quizá exagerada- de ello pueden ser los cuestionamientos éticos que le hicieran a Brett Kavanaugh en el trámite por ante el Senado a los fines de su incorporación a la Corte Suprema de Estados Unidos por su comportamiento en una fiesta cuando tenía 18 años. En esa sintonía puede entenderse que un relativista moral como Hart frente a la creación y discrecionalidad judicial en los casos díficiles, invoque la necesidad de "virtudes judiciales" como: "imparcialidad y neutralidad al examinar las alternativas; consideración de los intereses de todos los afectados; y una preocupación por desarrollar algún principio general aceptable como base razonada de la decisión". ${ }^{79}$

En el espacio iberoamericano durante el presente siglo se ha ido instalando el tema de la ética judicial de manera visible y extendida. El Estatuto del Juez Iberoamericano en 2001, la Carta de Derechos de las Personas ante la Justicia en el Espacio Judicial Iberoamericano en 2002 y el Código Modelo de Etica Judicial para Iberoamerica de 2006 que tuvimos el honor de redactar junto a Manuel Atienza por encargo de la Cumbre Judicial Iberoamericana. En la Exposición de Motivos de este último documento se consigna que: se asume "como compromiso institucional con la excelencia y como instrumento para fortalecer la legitimación del Poder Judicial"; que la ética judicial es "apelación al compromiso íntimo del juez con la excelencia y

79 Hart, Herbert, El concepto del derecho, trad. de Genaro R. Carrió, Buenos Aires, Abeledo Perrot, 1963, p. 253. 
con el rechazo a la mediocridad"; que el Código es "explicitación de la idoneidad judicial y complemento de las exigencias jurídicas en el servicio de justicia" y un "estímulo para fortalecer la voluntad del juzgador y pauta objetiva de calidad ética en el servicio de justicia".

En la filosofía moral y en la teoría jurídica asistimos en las últimas décadas a una verdadera restauración de las virtudes. Más aún, está la propuesta de "Virtue Jurisprudence" 80 que en definitiva postulan que en orden a procurar el mejor derecho lo decisivo es "quien lo hace" y no "cómo se hace". En ese llamado "giro virtuoso" o "giro aretaico" hay autores anglosajones muy difundidos en la actualidad como Martha Nussbaum, ${ }^{81}$ Michael Stole, ${ }^{82}$ John Deight, ${ }^{83}$ entre otros, pero también tenemos autores en nuestra lengua como Amalia Amaya, Guillermo Larriguet o Luciana Samané que mucho han aportado en aquella recuperación llegando a proponer que la teoría de la argumentación asiste a nueva etapa "que tiene que ver con la pregunta por el papel de las emociones en el contexto de justificación judicial". ${ }^{4}$ Desde otra perspectiva teórica, también habla de virtudes judiciales Manuel Atienza "como ciertos rasgos de carácter que deberían poseer -y quizás posean- los jueces" ${ }^{\text {"5 }}$ que posibilitan cierta anticipación o previsibilidad de las soluciones jurídicas para los casos concretos. El catedrático de Alicante, apoyándose en MacIntyre vincula al "buen juez" con esas virtudes judiciales, en cuanto cualidades adquiridas, cuya posesión y ejercicio promueven modelos de excelencia y la obtención de ciertos bienes internos

80 Solum, Lawrence, "Virtue Jurisprudence. A Virtue-Centre Theory o Judging", Metaphilosophy, núm. 34, 2003.

81 Nussbaum, Martha, "Emotion in the Languaje of Judging", St. John's Law Review, vol.70, núm.1, 1996.

82 Slote, Michel, "Empathy, Law and Justice", en Amaya, A. y Hock Lai, H. (eds.) Law, Virtue and Justice, Oxford, Hart Publishing, 2013.

83 Deight, John, "Empathy, Justice and Jurisprudence", The Southern Journal of Philosophy, 2011, vol. 49.

84 Larriguet G. y Samané L., "El papel justificatorio de la compasión en el razonamiento judicial”, en Emociones y virtudes en la argumentación judicial, México, Tirant Lo Blanch, 2017, p. 81.

85 Atienza, Manuel, "Virtudes Judiciales", en Jueces y Derecho, México, PorrúaUNAM, 2004, p. 17. 
específicos. El núcleo de la tesis acerca de las virtudes judiciales es que hay ciertos rasgos adquiridos en el carácter o la personalidad de algunas personas que los hacen más idóneos para cumplir la función judicial; aunque aclara Atienza que "las virtudes de los jueces no pueden ser muy distintas de las que caracterizan a otras profesiones o prácticas sociales... las virtudes básicas (las virtudes cardinales de origen griego) reciben una cierta modulación en razón de las peculiaridades de la práctica judicial". ${ }^{86}$ Coincidimos totalmente con Josep Aguiló cuando conecta las concepciones teóricas del derecho con visiones sobre ética judicial. ${ }^{87}$

En el ámbito de la razón práctica dialógica propuesta por Habermas y seguida por Alexy, una de las exigencias de la misma es la sinceridad de los participantes y la pretensión de corrección a los fines de alcanzar la verdad práctica, por ende, eso habla de una cierta exigencia moral del discurso moral general que se hace presente en el discurso jurídico a tenor que éste es un caso especial de aquel. El profesor de Kiel es categórico en sostener que las afirmaciones y decisiones jurídicas plantean necesariamente una pretensión correcta, y negarlo implicaría una incorrección moral, además de "contradicción performativa”. Frente a los riesgos de las éticas intersubjetivas dialógicas de prescindir de la dimensión subjetiva de la moralidad, es interesante traer a colación la palabra de una autorizada representante de dichas perspectivas, como lo es Adela Cortina, quien afirma: "...creo que a lo largo de la polémica entre neoaristotélicos y neokantianos se ha ido configurando un concepto excesivamente pobre de ética procedimental, un concepto que puede ampliarse reconstruyéndolo desde las ideas de valor y telos, hasta dar lugar incluso a una ética de virtudes o de actitudes, que complementará el reciente discurso de Habermas sobre la justicia y la solidaridad...." 88

86 Atienza, Manuel, “Ética Judicial” en Cuestiones judiciales, México, Fontamara, 2011, p. 153.

${ }_{87}$ Cfr. Aguilo, Josep, “Dos concepciones de la ética judicial”, Doxa, núm. 32, pp. 515-540.

88 Cortina, Adela, "La ética discursiva”, en Camps, Victoria (ed.), Historia de la Etica, t. III, Barcelona, Crítica, 1989, p. 554. 
En el pensamiento clásico la verdad práctica requería la conformidad con la intención recta (“...conformidad que no tiene lugar en las cosas necesarias, que no dependen de la voluntad humana, sino solamente en las cosas contingentes" ${ }^{19}$ ) e igualmente de la razón práctica prudencial o concreta. Para que haya sentencia justa, es indispensable que se quiera dictarla y también que la razón discierna la mejor alternativa. En el Aquinate dentro de los distintos modos de la injusticia, está aquella que remite a la intención o motivación, y en la explicación de Finnis agreguemos el ejemplo cuando la autoridad "explota sus oportunidades para adoptar disposiciones por las que no intenta el bien común sino en beneficio suyo o de sus amigos o de su partido o de su facción, o movido por malicia contra alguna persona o grupo". ${ }^{90}$

Frente a la alternativa de llamar deontología a la ética o moral profesional nos hemos opuesto principalmente con argumentos etimológicos. En efecto, en aquella expresión inventada por Jeremy Bentham el centro se pone en el deber (deonto), al modo en que procede el derecho; pero en la ética o la moral el acento está en el bien, que una vez escogido vendrán los deberes a cumplir para alcanzarlo. La ética judicial al pretender el mejor juez posible, procura convencerlo para que asuma el compromiso con la excelencia en el servicio, tanto en el ser como en el parecer, mostrándole a esos fines persuasivos los bienes (personales, sociales, institucionales, etcétera) posibles a obtener, y que de ese modo no se limite a ser un juez mediocre limitado a cumplir los deberes jurídicos. Hay una cierta pedagogía ética al respecto, que asumen las sociedades premiando con monumentos, poniendo los nombres en las calles, etcétera, en favor de aquellos que han asumido el servicio entregando todo lo que estaba a su alcance, por sobre de las exigencias jurídicas. Seguramente la sociedad no le brindaría ningún poder al profesional si previamente confesara que cumplirá su trabajo mal o mediocremente, por eso, no seguir la ética es no corresponder al privilegio que se le concede al profesional. Por supuesto, que, si no hay ética objetiva y cognoscible,

Aquino, Tomas de, Suma Teológica, I-II, q.57, a.1.

Finnis, J., Ley natural y derechos naturales, cit., p. 380. 
todo el discurso precedente y los códigos de ética profesional tiene que remitirse a la irracionalidad o gustos personales e interesados.

\section{Conclusión}

La experiencia moral del nazismo tuvo enormes proyecciones, y el mundo cambia en los más variados aspectos a lo largo de la segunda mitad del siglo XX. Esos cambios en el campo de nuestro interés implicaron la sustitución del EDL por el EDC, y consiguientemente una nueva propuesta de derecho, de Estado, de jurista y de las teorías que se requerían para comprender y operar en el nuevo paradigma. El campo analizado en este artículo toca un punto neurálgico de enormes proyecciones. La rehabilitación de la razón práctica facilita esos puentes que se construyen entre el derecho y la moral, pero claro está que, si no hay razón capaz de definir lo bueno o lo malo, lo justo o lo injusto, se frustra esa alternativa y se mantiene la distancia entre aquellas dos realidades y disciplinas.

Hemos tratado de mostrar que si hay moral racional, ya no podremos aceptar cualquier contenido como derecho (i); pretenderemos que al momento de crear o aplicar el derecho esté presente la moral racional para que el mismo sea el mejor posible (ii y iii); confiaremos el más completo conocimiento jurídico a quien asume una moral racional (iv); no tendremos reparos en reconocer el derecho a la objeción de conciencia fundada en una moral racional (v); resultará importante procurar que el derecho sea armónico con la moral social racional facilitando así su eficacia no coercitiva (vi); se podrá apelar a que el derecho supere su perspectiva sancionatoria y se preocupe por reconciliar la vida social a través de medios morales (vii); asumiendo el para qué o el sentido del derecho no solo nos encontraremos con la justicia y el bien racional,sino que también dejaremos de lado las tentaciones juridicistas (viii); y, finalmente, advertiremos que la ética del operador es una pieza decisiva si queremos el mejor y más legítimo derecho (ix).

No son los presentes tiempos fáciles para mantener irresponsablemente inercias. Hay una sociedad muy demandante y cuestionadora de toda autoridad. Esas voces también se destinan al derecho y 
a los juristas, y una de las demandas más claras e insistentes es por una vida buena asentada en la justicia, pero si la razón práctica nada puede decir al respecto, sólo queda el camino del poder para esas definiciones. No se trata de coartar libertades o imponer morales a los ciudadanos, se trata de reconocer y proteger bienes humanos básicos que la razón —-también jurídica- puede aprehender de manera elemental y que la vida social buena no puede suprimir sino promover.

\section{REFERENCIAS}

Aguilo, Josep, “Dos concepciones de la ética judicial”, Doxa, núm. 32. AlEXY, Robert, Derecho y Moral.

AlEXY, Robert, “La justicia como corrección”, Doxa, núm. 26, 2003.

AlEXY, Robert, "Algunas reflexiones en torno a cómo mi pensamiento jurídico ha ido desarrollándose con el paso de los años", en Bernal Pulido, Carlos (ed.), La doble naturaleza del derecho, Lima, Palestra, 2011.

AlEXY, Robert, “Derecho y Moral”, en La institucionalización de la justicia, Granada, Comares, 2016.

AlEXY, Robert, Derecho y razón práctica, México, Fontamara, 1993.

AlEXY, Robert, "Derechos fundamentales y estado constitucional democrático", en Carbonell M.(ed.), Neoconstitucionalismo(s), Madrid, Trotta, 2003.

AlEXY, Robert, El concepto y la validez del derecho, Barcelona, Gedisa, 1997.

ALEXY, Robert, "La naturaleza de la filosofía del derecho", Doxa, núm. 26, 2003.

ALEXY, Robert, Teoría de la argumentación jurídica, Madrid, Centro de Estudios Constitucionales, 1989.

AlEXY, Robert, Teoría del discurso y derechos humanos, Bogotá, Universidad Externado de Colombia, 1995.

Aquino, Tomas de, Quodlibetum, 1,9,3. 
Aquino, Tomas de, "Scientia moralis docet hominis sit bona ex hoc quod et secundum rationem rectam..., Comm. Eth. L.2, lec.2.

Aquino, Tomas de, "Scriptum Super Libros Sententiarum Petri Lombardiensis", IV.

Aquino, Tomas de, "Suma Teológica" I-II.

Aranguren, José Luis, "Ética”, Revista de Occidente, Madrid,1958

ARISTóteles, Ética Nicomaquea, VI,5,1140 b 5.

Atienza, Manuel, Ética Judicial en Cuestiones judiciales, Fontamara, México, 2011.

Atienza, Manuel, "Virtudes Judiciales”, en Jueces y Derecho, México, Porrúa-UNAM, 2004.

Bernal Pulido, Carlos, La doble dimensión del derecho, Lima, Palestra, 2011.

Bоввіо, Norberto, "Dalla struttura alla funciones", Milán, Edizioni di Comunitá, 1984.

Boввіо, Norberto, “Derecho y ciencias sociales", en Boввіо, Norberto, Contribución a la teoría del derecho, Fernández Torres (eds.), Valencia, 1980.

Bоввіо, Norberto, "La función promocional del derecho", en Boввіо, Norberto, Contribución a la teoría del derecho, Fernández Torres (eds.), Valencia,1980.

CAlsamiglia A., "Teoría del participante versus teoría general del Derecho: una aproximación", Anuario de Filosofía del Derecho, Madrid, t. XIII y XIV (1996-1997).

CortinA, Adela, "La ética discursiva”, en Camps, Victoria (ed.), Historia de la Etica, t. III, Barcelona, Crítica, 1989.

DEIGHT, John, "Empathy, Justice and Jurisprudence", The Southern Journal of Philosophy, 2011, vol. 49.

Dworkin, Ronald, Los derechos en serio, Barcelona, Ariel, 1984.

Finnis, John, Aquinas. Moral, Political and Legal Philosophy, Oxford, Oxford University Press, 1998.

Finnis, John, Aquinas. Moral and Legal Theory, Oxford, Oxford University Press, 1998. 
FinNis, John, Collected Essays, vol. I, "Reason in Action", Oxford, Oxford University Press, 2011.

FInNIS, John, Ley natural y derechos naturales, Buenos Aires, Abeledo Perrot, 2000.

GILson, Etienne, El realismo metódico, Madrid, Rialp, 1963.

GonzÁlez Álvarez, Ángel, Manual de Historia de la Filosofía, Madrid, Gredos, 1960.

HART, Herbert, El concepto del derecho, trad. de Genaro R. Carrió, Buenos Aires, Abeledo Perrot, 1963.

Hierro, Liborio, La eficacia de las normas jurídicas, México, Fontamara, 2010.

KALINOWsKI, George, "Application du droit et prudence", Archiv für Rechts und Sozialphilosophie, L.III/2, Wiesbaden, 1967.

Kelsen, Hans, Teoría pura del derecho, Porrúa, México, 2000.

Kemelmajer de CARlucci, Aída, Justicia restaurativa, Rubinzal-Culzoni, Santa Fe,2009.

LaChance, Louis, El concepto de derecho según Aristóteles y Santo Tomás, Buenos Aires, 1953.

LARRIGUET G. y SAMANÉ L., "El papel justificatorio de la compasión en el razonamiento judicial", en Emociones y virtudes en la argumentación judicial, México, Tirant Lo Blanch, 2017.

MacCormick, Neil y Weinberger, Otta, An Institutional Theory of Law, Dordrecht, D. Reidel, 1986.

MacCormick, Neil, "The Separation of Law and Morals", en GEorge, Robert P., Natural Law Theory-Contemporary Essays, Oxford, Clarendon Press.

Martinez Doral, José M., La estructura del conocimiento jurídico, Pamplona, EUNSA, 1963.

MASsini, Carlos I., El derecho natural y sus dimensiones actuales, Buenos Aires, Abaco, 1998.

MASSINI-Correas, Carlos I., Jurisprudencia analítica y derecho natural, Madrid, Marcial Pons, 2019. 
Michel Slote, "Empathy, Law and Justice", en AmAYA, A. y Hock LAI, H. (eds.), Law, Virtue and Justice, Oxford, Hart Publishing, 2013.

Millan Pueles, Antonio, Ética y realismo, Madrid, Rialp, 1996.

Nino, Carlos S., Ética y derechos humanos, Buenos Aires, Paidós, 1984.

Nino, Carlos, "Sobre los derechos morales", Doxa, núm. 7.

NussBaum, Martha, "Emotion in the Languaje of Judging", St. John's Law Review, vol. 70, núm. 1, 1996.

PIEPER, Josef, Las virtudes fundamentales, Madrid, RIALP, 1976.

PoRTELA, Jorge Guillermo, La justificación iusnaturalista de la desobediencia civil y de la objeción de conciencia, Buenos Aires, EDUCA, 2005.

ReIDel, Manfred, "Rehabilitierung der praktischen Philosophie", Freiburg i. Br., 2 vol.,1972-1974 y VoLPI, Franco, "La rinascita della filosofia pratica in Germania", en Pacchiani, C. (ed.), Filosofia pratica e scienza política, Abano-Padova, 1980.

Solum, Lawrence, "Virtue Jurisprudence. A virtue-centre theory o judging”, Metaphilosophy, núm. 34, 2003.

VIGo, Rodolfo Luis, "Consideraciones sobre la visión de John Finnis acerca de la tesis "la ley injusta no es ley", disponible en: http//biblio.juridicas.unam.mx.

VIGo, Rodolfo Luis, Perspectivas iusfilosóficas contemporáneas, Buenos Aires, Abeledo Perrot, 2019. 